\section{Journal of the British Association for the Study of Religions}

JBASR 21 (2020), 114-134

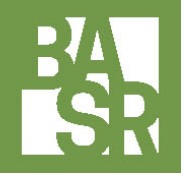

ISSN: 2516-6379

\title{
Marginalized centre: Wana people and the geography of power
}

\author{
Giorgio Scalici \\ NOVA University Lisbon \\ scalicigiorgio@gmail.com
}

\begin{abstract}
The Wana of Morowali (Indonesia) are nowadays a small endangered community marginalized by the Indonesian government, world religions and the other communities in the area but, according to their own mythology, they are not the periphery of the world, but the real centre of it.

Their cosmogonic myth tells how the Wana land (Tana Taa) was the first land placed on the primordial waters and it was full of mythical power, a power that, when the land was spread around the world to create the continents, abandoned the Wana to donate wealth and power to the edge of the world: the West. This myth has a pivotal role in the Wana worldview, their categorization of the world and the power relationships in it. The Wana reverse the traditional relationship between centre and periphery, placing themselves in a powerless centre (the village or the Tana Taa) that gave all its power to a periphery (the jungle or the West) that must be explored to obtain power and knowledge.

This relationship not only expresses a clear agency in shaping the relationship of power with forces way stronger than the Wana (Government and world religions) but also creates internal hierarchies based on the access to this knowledge; granted to men and partially precluded to women due to the cultural characterizations of these genders. Indeed, the majority of shamans, called tau walia (human-spirit), are men, and they are the only one that can travel between the human and the spiritual world, obtaining a spiritual and social power.

In this article, we will see how Wana categorise the world and use religion, rituality and gender to express their agency to cope with the marginalization by the government, the world religions and the other community in the area.
\end{abstract}

\section{KEYWORDS}

Marginality, indigenous culture, gender, myth 


\section{Introduction}

The Wana people are a small (around 5000 people) indigenous community living inside the Natural reserve of Morowali, Indonesia. The few anthropological works done on this community were made by the French film-makers Gerald Journet and Martine Nougarol (2005, 2007, 2011), the De to Wana op Oost-Celebes (1930) written by the Dutch missionary Albert C. Kruyt, and Jane Monnig Atkinson, who produced an analysis of the ritual lyrics in her book The art and politics of Wana shamanship (1992) and wrote a number of articles on other Wana-related themes (1983, 1987, 1992, 2003). More recently (2011), the German anthropologist Anna Grumblies (a PhD student at the time of my first fieldwork) was in the field investigating the relationship between Wana people and the external world. Her research has since been published: Being Wana, Becoming an "Indigenous People".

Experimenting with Indigeneity in Central Sulawesi (2013). Her essay discusses the concept of adat (tradition), Wana strategies to preserve their independence and coping with their marginality.

In this article, I engage with dependency theory and I argue that Wana people have a conception of centre and periphery that is diametrically opposed to the capitalistic and Colonial one; they value the centre as a powerless place while all the power is concentrated at the periphery. For them, Europe is powerful because it is on the peripheries, located far away from the centre of the world, where they are living.

While Grumblies discusses Wana marginality and their coping methods, I state that the Wana see themselves as the centre of the world, not the periphery. I believe that the contrast between my conclusions and those of Grumblies is largely due to the places of our fieldwork, placing both of us in the complex position to be both right and wrong at the same time. She spent her entire fieldwork period outside the Morowali forest, in the village of Taronggo where Wana people live together with Christians and Muslims, go to school, have access to modern medicine and are more in contact with the world outside the forest. I spent some time in Taronggo but my main research was done inside the forest. It is possible that, even though we both worked with Wana people, we are expressing two different points of view. I am reporting the point of view of the Wana people from the forest, the people that live in the powerless centre and that define the world around them from this position. Grumblies, on the other hand, is reporting the point of view of people living outside of that centre, in a liminal place between the forest and the periphery of the Wana world, where Wana identity is strongly influenced and shaped by the point of view of outsiders.

\section{In illo tempore}

To understand Wana vision of the world we need to look at their mythologies; stories that have helped the Wana in understanding the world around them. According to the stories I gathered, in the beginning there was 
only the sea before, one day, Pololoisong, the Wana trickster, asked Pue to create the world. Pue placed the first land onto the world in the form of the holy mountain/axis mundi Tunda $n^{\prime}$ tana, ${ }^{1}$ and continued his creation following the requests of Pololoisong. ${ }^{2}$ Tunda $n^{\prime}$ tana was connected to the sky, suruga, through a vine called a vaiansivangu, but the vaiansivang $u$ was gnawed at and severed by a mouse, causing the separation of the sky and the earth. This ended mythical time and signalled the definitive departure of Pue from humanity. It was also an event necessary for the survival of humanity, since the nearness of the sky to the ground made the temperature too high for life. The separation from the saruga and the subsequent end of mythical time is a pivotal idea in Wana culture; it marks the start of what they consider to be their "miserable" life. The myth of the broken vine or a more general axis mundi can be found in other cultures too (Eliade 1972; Geertz 1973). Since the end of mythical time, this link between the ground and the sky has remained accessible only to certain kinds of beings (spirits and shamans).

At the request of Pololoisong, Pue began to create the animals. First, he created chickens, and this led to no significant changes on Earth. Then he created pigs, which started rooting around and spreading earth into the water around Tunda n'tana and, while the mountain became smaller, landmasses and islands were created. On another day, Pue created trees when Pololoisong asked for something to help avoid the heat. Among the trees was the special kayu paramba, on which money grew instead of leaves. If the kayu paramba had been cut down in a proper manner, it would have brought riches to the Wana people. However, Pololoisong did not care about the money and did not follow Pue's instructions for felling the tree. He did so wrongly, allowing it to fall into the sea. Pololoisong used the fallen tree as a canoe to travel with the money to the West, perhaps the Netherlands, while condemning the Wana people to a life of misery. Grumblies reports that one of her interlocutors commented on the presence of the kayu paramba in the West in this way: "[the West] where white and rich people live. If the tree had landed on the earth, maybe you would now be poor and Wana people would be rich" (2016: 102). Similar ideas are common among indigenous people all around the world; one example is Tyeat Nutyok, the mythical hero of the Huave of Mexico. He goes away to the USA, bringing to them science and technology, and the Huave are left poor (Bresciani 2020).

Pololoisong is also the creator of the first couple: Tau Santoto and Delemontu. They had 16 children, eight sons and eight daughters, each the archetype of a human action; they were the first farmer, the first hunter, and so on. These mythical children are called tau Baraka (the people of mythical time) and were so powerful that they could make anything appear in front of them just by closing an eye and pronouncing a spell: "Adi adi of mother and father, mine is the truest (knowledge); I just have to open my eyes..." (Atkinson 1992: 43). Pololoisong's departure to the West ended this golden era in which these mythical people lived, as the tau Baraka also left to go to Joe

\footnotetext{
${ }^{1}$ The sacred mountain is also known by Wana people under another name: Taman Sari, a Javanese word that means "beautiful garden."

${ }^{2}$ Poloisong has a younger brother: Adi Banggai. While Poloisong, as a Wana cultural hero, was illiterate, the younger brother was the first Muslim and he knew how to write.
} 
$n^{\prime}$ tana (the place at the end of the world). One day, however, they will return to begin a new mythical era.

The event marking the end of the mythical time began the erosion of the power of the Wana land and the diffusion of its power around the word. Atkinson claims that "over time, [...] Wana have grown smaller and weaker. Time, by the Wana equation, spells degeneration" (1992: 49). I agree with Atkinson but I would say that space, and not time, spells degeneration. According to my observation of Wana culture and their conception of time, it is not time that creates a degeneration, because time is something Wana do not consider, but it is the distance from the mythical space/time, something concrete that it is not temporally but spatially far away. The mythical West is not happening in the past but it still happening now, along with Wana reality and time almost parallel to it. The myth is in another space more so than another time, and the power of the Wana is directly proportional to the proximity of the mythical reality.

Moreover, the first Wana people lived together on a spinning top until the day it broke, and they moved all around the Wana land. With the passing of time and the increase in their number, they lost the mythical power of their ancestors. It is reasonable to note a direct connection between the unity or density of the mythical time and a loss of power related to the decrease of that original density, the dilutions of the state of perfection. In some ways, the fractures of the mythical vine and of the spinning top can be compared to the explosion of the big bang, which saw an originally dense mass expand and decrease in density, and a weakening of gravity. Wana society, despite being at the centre of the world, has lost all its mythical people, and those left behind consider themselves the poorest people in the world.

\section{The Wana people and the others}

Like Atkinson (1992) before me, I was struck by the widespread sense of inferiority that Wana people seemed to show during my time with them, in a form of introjected racism. More than once, I heard people call themselves or their ancestors miskin (poor) or other negative epithets. Apa Rahu, who was around $65^{3}$ at the time (2011), told me that his grandfather fought in the wars between tribes and that he was so miskin that he had to dress himself in leaves and coconuts. ${ }^{4}$ In his words "We did not have clothes because we were miskin." ${ }^{5}$ Atkinson's observations are strongly worded:

Wana are fully aware that they are at the bottom of an ethnic ladder, dominated and despised by their neighbours - Bugis, Mori, Pamona, Gorontalo, and others - who subscribe to one or another world

\footnotetext{
${ }^{3}$ Apa Rahu's age is a personal guess. Wana people do not count years or birthdays, and then it is very hard, if not impossible, to know the exact age of older people.

${ }^{4}$ Even the lack of cloths is considered a consequence of the exodus of the tau baraka. Atkinson reports that even sewing is considered a skill of the mythical time. Leaves, bark cloth and coconuts were "considered by the Wana to be grievously inferior to cotton cloth" (Atkinson 1979: 65) and another proof of their miserable life.

${ }^{5}$ Interview recorded in March 2011.
} 
religion. Wana represent themselves as poor and degraded (Atkinson 1990: 55).

It is possible that this tendency to deprecate themselves originates in a cultural predisposition related to the myth of the fall that we saw earlier, combined with the effects of a subordinate power relationship with foreign powers such as Indian, Islamic and Dutch colonizers. The relationship between the Wana people and outsiders seems to have shaped their vision of themselves and their reality and is possibly pivotal to this negative selfevaluation. To better understand the relationship between the Wana and the periphery we need to look at their history. By the fifth century $\mathrm{CE}$, commerce between Indians and the population of the Indonesian archipelago was already flourishing, although the Indians never obtained control of the hinterlands of the main islands of Java, Sumatra, Borneo and Sulawesi (Scarduelli 1992: 42). It is likely, then, that the Wana people living in the hinterland mountains did not have much contact with the sultanates of Central Sulawesi, while it is documented that the Wana of the coastal settlements paid tributes to the sultans of Ternate and Bungku around 1257 (Alvard 2000: 59). The name Wana itself derives from Sanskrit and means "forest" (Ibid.), and this confirms that there was contact between this group of people and Indian culture. "The Wana may have taken as a name for themselves a term applied by outsiders to the inhabitants of the rugged forest interior" (Atkinson 1979: 5).

Between the 15th and 17th century, the Kingdom of Luwuk of South Sulawesi extended its interests through Morowali and Poso regencies into Wana territory. Central Sulawesi was under the control of the kingdoms of Makassar, Mandar and Ternate (Sangaji 2007: 325). According to Atkinson, the influence of the latter was so important that Wana people consider the Raja of Tenerate their first king (Atkinson 1992: 335). Around the year 1450, Islamic traders started their expansions into Indonesia (Wagner 1960: 87) and many of these kingdoms began to transition from Hinduism to Islam. Like the Hindus before them, these Muslims could not impose themselves on the hinterlands. The difficulties encountered into penetrating into inner areas (especially in the big islands: Sumatra, Borneo, Sulawesi) do not allow us to define the process in terms of conversion: what happened was a gradual absorption of Muslim religious principles, a partial and selective assimilation within the indigenous cultural context (Scarduelli 1992: 46). Li points out how "in economic and political matters the relationship between upland [internal] and lowland [coastal] systems has long been marked by tension" (Li 1999: 8). The relationship between the coastal kingdoms and the inner community was not egalitarian and the latter were considered "inferior and treated in a derogatory way" (Hauser-Schäublin 2013: 13).

The first communities of Dutch missionaries started to populate the Morowali area around the two World Wars. Atkinson writes of a contact that ended in armed conflict between the Dutch and the Wana in 1942. Relations with Christian missionaries, already recorded by the missionary Albert Kruyt in the 1920s, increased in 1979 with the arrival of the New Tribes Mission, an evangelical missionary group from the United States and Canada (Atkinson 
1991: 45). A new wave arrived in 2015, just before my second period of fieldwork.

For some Wana individuals, becoming Christian means to become somewhat "peripher-ised", hence they can feel superior to others around them. Atkinson reports strong evidence of this complicated relationship between Wana people and Christianity already emerging in the 70s: "Some report having been told to their face that they lack the personal worth of a dog or a chicken because they have no religion" (Atkinson 1991: 46). I also experienced first-hand Wana Christians treating non-Christians as inferior and looking down on them for still believing in spirits. In villages such as Taronggo, Wana Christians often show an attitude of superiority towards their relatives from the jungle, to the extent that the latter might be banished to an isolated space during a wedding feast. My guide Ajeran confirmed to me that this was exactly the case I witnessed, and that the family was ashamed to have relatives considered "primitives" by the people living outside the forest and the converted Wana. In her thesis, Grumblies perfectly describes that event:

He [Apa Ele, the father of the bride] invited those guests who stand or sat close to the dining tables to the big buffet. Then he turned to his keluarga dari gunung (BI), his family from the mountain, and explained to everyone that there was not enough space for every guest to eat from the dining tables and not enough chairs. And because his mountain relatives were not comfortable with sitting in chairs or eating from plates, he invited them to take their meal in the nearby town hall around the corner, where they could sit on the floor and eat with their hands as they prefer to; instead of plates the food would be served in banana leaves. (2016: 168)

Thanks to this vivid narration, we see how the discriminations against the Wana are manifest. The "town" people take advantage of their position and, artfully, reserve for the Wana people a second-class service, writing it off as doing them the favour of allowing them to follow their usual "habits". Grumblies then corrects her statement about the same food being served to everybody:

[Wana] generally are believed to dislike beef (a fact that is simply not true; my interlocutors stated they indeed like beef, but they rarely get the chance to taste it). "They are happy with chicken, why should we serve them cow?" one of my Christian interlocutors replied when I asked about this circumstance. Wana usually were not always aware of such acts or processes of (symbolic) violence as directed towards them. Some distinctions were internalized relations people were not actively recognizing as actions of differentiating (2016: 169)

I have already noted that, as early as the 1970s, when Atkinson was in the field, similar conflicts with the Christians were already occurring, while the relationship with Muslims was friendly. According to her, Islam accepts and 
permits Wana shamanistic practices, while Christians completely refuse them and consider them sinful. Christianity is considered a religion for powerful people and it gave access to modern comforts (hospitals, schools and medicines). "Christianity puts a poor Wana in a bind, people say, for either one must sit by and watch loved ones die or one must commit a sin by calling on traditional forms of aid" (Atkinson 1988: 53). Nowadays the situation is slightly changed, with few schools, medical centres and pharmacies available to the Wana, but the power relationships did not change. As Atkinson and I observed, the Christian identity is strongly interconnected with ideas of class and status. Atkinson follows up with a stark illustration: "People tell of being told [by the Christians] their necks will be cut like chickens, their genitals split open and rubbed with salt, for their human worth is less than that of dogs refusing religion" (Atkinson 1979: 32). Nowadays the situation is less violent but nonetheless tense. Christians and Wana remain two separate words, both culturally and socially, with the Christians in a position of power, due to their relationship with the powerful periphery, and an intolerant or haughty attitude towards the Wana life, considered a shameful trace of the past.

\section{Space and power}

Due to the important role that the juxtaposition of centre and periphery plays in Wana reality, I will now explore this relationship with the intention of understanding how Wana people categorise space and place themselves in it. The division of space in patterns of concentric circles has an impact not only on the way Wana people interact with the world, but also on how they understand themselves and their emotions. These concentric circles have different degrees of mythical power, and access to each space is limited to different categories of beings: humans, shamans, men, women, tau Baraka, and so on.

Grumblies explains that her thesis is:

about people who are described as marginal and who consider themselves marginal. But it is also about people who have developed their very own understanding of their marginality and who have recently started to use their marginal position as a powerful tool to counteract marginalization processes directed towards them (2016: 6).

While this is necessary and valuable work, I must again point out a crucial difference in our two approaches. When Grumblies labels the centre and the peripheral, she does so from a point of view that is more etic than emic, accepting that the Indonesian government represents a natural "centre." In many ways, her reflections are quite justified, not least because even the Wana people themselves have internalised this sense of their own isolation and marginalisation (meaning that they recognise having been forced into a position of powerlessness). I argue, however, that taking an emic point of view, the whole idea and the characteristics of the centre and the periphery are completely inverted. As Harms et al. point out "remoteness is never fixed; 
it is not a predetermined and enduring place but a process situated in dynamic fields of power. The condition is always infused with the edgy feeling experienced by people living in a world where the relations of inside and outside, near and far, proximate and remote are always contested" (Harms et al. 2014: 364). It is clear that the concept of marginality is a complex one (Dennis 2007: 2763). The centre is generally understood as a realm with a dense concentration of power, while the periphery is where the energies, power and control of the centre is looser.

Wana people, however, conceive of a world in which the centre is a place that used to have a high concentration of power but that is now powerless, while the periphery now has real power but only because it took it from the centre. Moreover, Grumblies affirms that "Wana see their land as the navel of the world, pusen tana. This land is furthermore, the source of baraka (power), kasugi (wealth) and pagansani (knowledge)" (2016: 103, emphasis in the original). Therefore, the very idea of being marginalised or peripheral is turned on its head; Wana people are aware that they are powerless due to mythological and historical reasons, but their powerlessness derives from their central position, not from their place on the periphery. After all, as scholars such as Tsing (1993), $\mathrm{Li}$ (2000) and Hussain (2009) have all explored, centre and periphery are social constructions and vary culture by culture. Shils, in his The Constitution of Society, suggests that every society considers the centre to be a point of reference because it establishes "the order of symbols, of values and beliefs, which govern the society" (1982: 93). He concludes that "It is the centre of the order of symbols, of values and beliefs, which governs the society. It is the centre because it is the ultimate and irreducible" (Shils 1982: 93). Shils seems to overlook the fact that for every centre there is a periphery. For Wana people, both have an important role, and their status has changed over time.

Following Shields' (1991) idea that each space has a specific rank in relation with other spaces, I will now try to describe the ways in which Wana people rank their geography based on distance from the "centre." The world outside the villages and the jungle is divided into areas. The closest to the Wana land is Indonesia, a liminal place hovering between them and the mythical West. Apa Rau dreams of and talks about Jakarta as a "heavenly city," but it is also a world that is known to Wana people, since they go there to trade goods and to buy objects such as TVs, movies and t-shirts, all of which have an origin that is mysterious to them. This lack of "density" and the dispersal of mythical power from the Wana land towards the West has a deep influence on how Wana people divide the world and interact with it. Looking at Wana people's division of the world, there is the village at the centre; this is the place of the human. The village is the place of culture, but no power from mythical time remains here. Outside there is the jungle, the place of the spirits. The jungle is where people go to look for knowledge and to become shamans. It is generally considered a dangerous place, but Wana men travel and even sleep in the jungle without any fear. I have already clarified that the concept of the centre is subjective and locally constructed; each village is the centre for the people who live there, but at the same time, on a more universal level, the religious centre of the Wana land and the world in 
general is the Tundantana mountain and the village located there, Uewaju. Therefore, on one hand the real centre of the world is the sacred mountain, but on the other hand, in daily life it is one's own village. From each village, each inhabitant's life spreads into outside realms.

For the Wana, the West is a category and not a direction; everywhere outside of the Wana land, no matter in which compass direction it lies, is considered the West and a mythical place. Indeed, the mythical character of the West is manifest in the wealth of all of its inhabitants, that its streets are made of gold, and that everything is full of power. During fieldwork, even I was considered almost a mythical person; people wanted to touch me, and my belongings were considered extraordinary. It is for this reason that I represent how Wana people categorise the geographical world as a series of concentric circles (Img. 1). At the edge of the world there is the Joe n'Tana where mythical people dwell. Again, according to myth, mythical people that once moved from the Tana Wana to the edge of the world will one day come back to the Wana land, bringing back Wana people's lost power and prosperity, and re-establishing the integrity and density that was lost with their departure.

A criticism of this concentric circle model is that it only takes into consideration horizontal space and does not incorporate the vertical plain of Wana reality. This verticality is a feature of the world as it is in relation to the sky over the Tunda'n tana. In this world there is Pue and the afterlife, while the underground, even if in the past it was considered a separate realm with its own god, is nowadays almost ignored by Wana people. My reasons for focusing on the horizontal is that, in the Wana case, there is no reason to consider vertical and horizontal as opposites. Instead, I represent the Wana world as a series of concentric spheres, with the Wana land at the core, and the Jo n'Tana at the outer border, and in between there is the West and the afterlife. In Wana culture the West and Pue have the same "mythical grade." Wana people move in horizontal plains, but shamans can move both vertically, to visit the afterlife, and horizontally, to the West. Even the dead, who follow the pole in the dumbaru to reach the afterlife, are usually described as travelling eastwards. The key to this apparent contradiction is that Wana people do not give the same value and sense to cardinal directions when talking about power, and that these issues are more matters of distance than direction. 


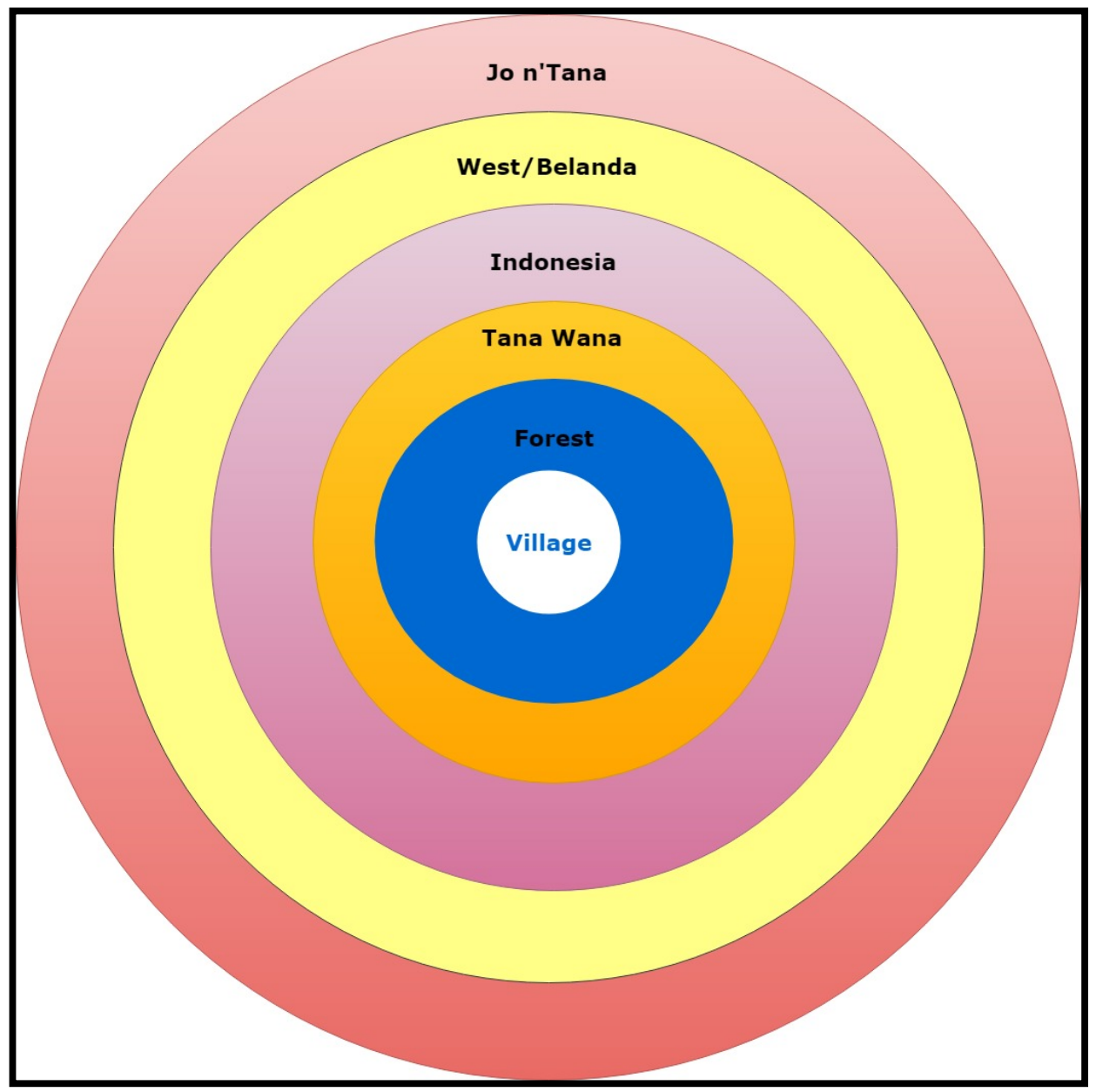

Img. 1: Representation of how Wana people conceptualise the geographical world.

\section{Space and gender}

I see, then, all of Wana reality and rituality as constructed upon this juxtaposition between centre-powerless and periphery-powerful and the constant movement between spaces. Each day, Wana men move from their house to the jungle to work (collecting rattan or resin), to hunt (bats, monitor lizards, wild pigs) or, in the case of some from the villages closer to the borders of the jungle, to travel to the outside to trade. They then return to the village. On the other side, Wana women stay in their homes or villages, or go to their gardens, which are considered part of the village. Here it is evident that Wana culture divides space between genders. ${ }^{6}$ In her essay 'Gender in Wana Society' Atkinson offers a fascinating discussion of the role and value that women and men have in this society, and she often underlines how

\footnotetext{
${ }^{6}$ Wana people have terms for male and female, and they are aware of homosexuality. I never encountered any homosexual couples, although it is possible this was a matter of homosexually not being expressed openly. Outside the forest, I met gay men, a lesbian couple living together and a transgender person. These people are accepted and not considered negatively at all, but I never witnessed open homosexuality among Wana people. Atkinson writes about women who transition to becoming men but not of men becoming women, and these passages were complete, considering that one of the examples had a wooden penis and a wife (Atkinson 1990).
} 
"Although men and women may be the same sort of beings going about their tasks in Wana communities, men gain something extra by travelling farther in the realms of both the wilderness and the state" (Atkinson 1990: 80).

Travelling far is what actually differentiates male and female among Wana people. While it might seem obvious to point out gender differentiation in sex and procreation, actually "the participation of men and women in the process is conceptualized not as complementary, but as identical. Both sexes menstruate, both become pregnant, and both are the "source" of humanity" (Atkinson 1990: 77). Men and women are culturally considered equal, but space and labour are nonetheless clearly divided by gender. Men are linked to the space outside the village, where they hunt, work or simply travel. That space (the forest, Indonesia or even the West) is the place of spirits and knowledge; it is here that a shaman goes to learn about the world. Women are tied to the village; they almost never travel alone, and their tasks almost always concern life in the home. The crucial point is that there is no rule that forbids women from behaving in the same ways as men, but women simply do not do so. Often humour and jokes are used to control people's behaviour, but I never saw a woman patently blocked from covering a task usually performed by men. On the contrary, it seems that through education and cultural training Wana culture creates unconscious blocks that prevent women from reaching positions of power, such as shaman or village chief. In her analysis of gender relationships among Wana people, Atkinson states:

"Anyone" could become a shaman, a rice specialist, or a legal expert. That those "anyones" are predominantly male is treated as a fluke of fortune, rather than a categorical process of inclusion and exclusion. In this sense, Wana women represent the "everyman," the majority, who because of lack of bravery, fortune, good memory, or inclination never come to excel at what it takes to be a political leader in a Wana community (Atkinson 1990: 88).

I think that "inclination" is the key word; without specific rules blocking women from power, why are women not inclined to become shamans or a village chiefs? A simple answer might be that they are shy. Culture undoubtedly plays a crucial role in shaping the desires of people and how individuals interact with the world around them. For this reason, it is strongly possible that the shyness that characterises Wana women is a cultural tool that has been used by Wana society to control access to power. It effectively bars women from positions of power without the need for any form of physical strength to be used.

It has been suggested by Ortner (1996) that females are viewed as closer to nature and males as closer to culture. I take issue with this formulation in the Wana context. For Wana people, the village is a safe place of culture, while the jungle is a dangerous place of spirits and nature. If women are confined to their villages, it is because "nature" is considered too dangerous or, even more importantly, too powerful for them to be allowed to get close. Rather than there being an opposition between nature and culture, 
among Wana people, the real opposition is between humans and spirits. In this binary, men are closer to spirits than women. It is perhaps not a coincidence that nowadays the closest people to the spirits are shamans, and the great majority of them are male.

Even if, in terms of status, Wana people are fixed in their position of powerless centrality, in an everyday sense, they do move from the centre (the village) to external parts of their geography and return to the centre. I understand this as a constant combination of centrifugal and centripetal forces (Img. 2). These movements are reproduced in Wana rituality and in the different expression of emotion for men and women.

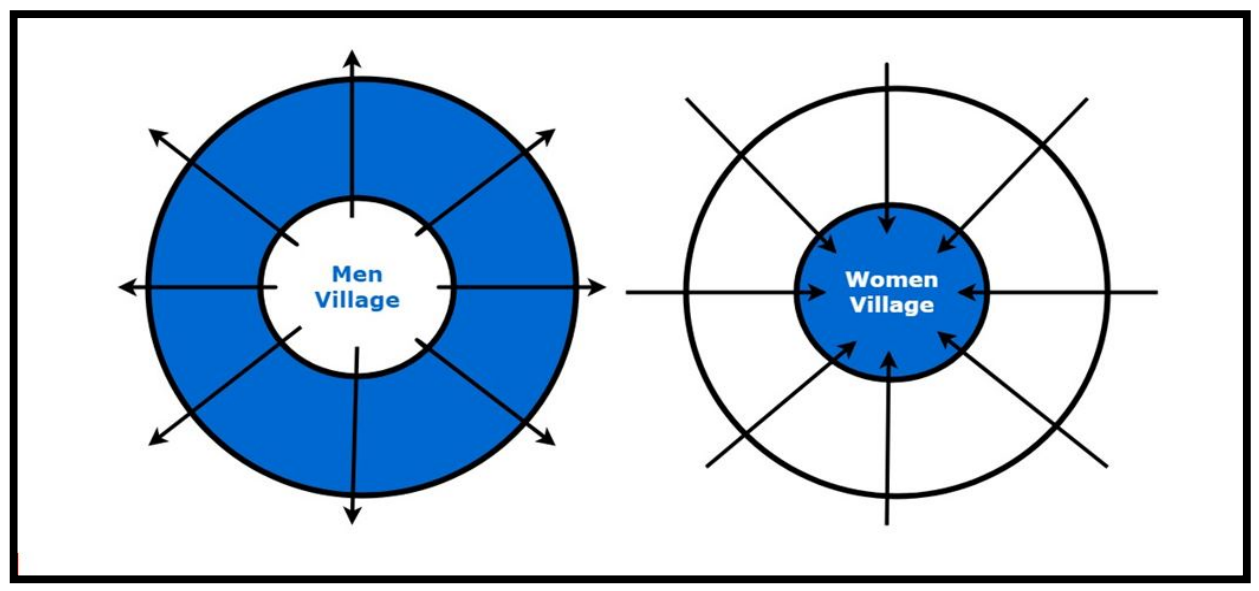

Img. 2: While the Wana men are the embodiment of the centrifugal energies, women embody the centripetal energies. Men have the freedom to go outside the village into the nonhuman world and obtain knowledge and power while women are kept at core of the powerless centre by their cultural training.

Atkinson briefly discusses similar issues, when she identifies as a central idea in Wana culture the movement forwards and backwards from different realms: "Wana associate the most valued forms of cultural knowledge with distance from their own settlements" (1990: 72).

There is no rule prohibiting women from becoming shamans, but instead that men make shamans more easily because they are more commonly seen travelling outside of the village and into the dangerous place of the spirits. "At the center of constellations of power" we find "the creation of identities and the microgeographies of everyday life" (Cresswell 2011: 551). The same happens during the momago (shamanic ritual). The shamans travel from the safe place of the house to explore the space outside the village, and at the same time outside of the human world itself, into the realm of spirits. This dangerous task is considered a male one because women are enculturated to be more reticent and shy. The conception of the world as divided into female and male spaces is important in the momago.

It is not a coincidence that Wana women are characterised by their "shyness," something that is recognised both by men and women. This shyness was noted by Atkinson in the 1970s and presented itself to me as a key feature of Wana culture and the gender differentiation in 2016 too. As 
Grumblies also notes "The 'timidity' is still an important point of selfreference and is deeply connected to a self-marginalization process [...] in which Wana often portray themselves as 'stupid,' 'poor' and 'helpless'" (2016: 226). This shyness or timidity, therefore, affects the whole Wana community and its vision of itself, but is particularly strong among women. To reconnect this trait to the lack of female shamans, it is worth mentioning that I never saw a woman under the age of 60 dance in a momago, and they explained this as being down to their shyness. This shyness among Wana women has the effect of keeping women outside of the spheres of power. It is interesting to notice how young Wana are not shy when dancing in other celebrations, such as weddings.

In "Gender in Wana Society", Atkinson discusses some elements of gender division among Wana people and concludes that "Wana underscore the fundamental likeness of the sexes and the complementary nature of their work" (1990: 63). She also clearly describes how their world is organised by gender:

The world of a conjugal unit is divided into gendered tasks. Men clear brush, fell trees, and burn plots for planting; women are primarily responsible for planting, weeding, and harvesting, although the last of these three tasks is in fact one in which both sexes freely participate. In addition, men hunt and both sexes forage for riverine and forest food. Men build houses and granaries; women make items like mats, baskets, and clothing. And, importantly, men travel long distances to coastal markets to trade Wana products like rice, resin, and in some areas, rattan, for cloth, salt, and metal implements (Atkinson 1990: 69).

The complementarity of the two genders is reflected in their daily tasks (cooking, working in the paddy, taking care of children and so on), some of which are shared by both sexes. The most important difference between the two genders is the relationship with the space around them: "Whereas women tend to be 'settled' (rodo), men go off to distant places from which come both danger and power" (Atkinson 1990: 71). More importantly,

Wana identify both women and men as life-givers. Asserting a fundamental likeness between the sexes, however, Wana culture celebrates powers removed by space and time from human settlements and defines access to these powers in a manner befitting men's, not women's, activities (Atkinson 1990: 79).

During the mandeke, the controlled explosion of grief, women tend to become smaller. They become an embodiment of the centripetal energies that control their lives, while men move more expansively in the space before calming down and closing their bodies on themselves like the women. Looking at Atkinson's research, it seems that similar contrasting behaviours were present 40 years ago: "men appropriately express their grief through displays of anger; women, by contrast, wail? (Atkinson 1990: 68). In addition, male 
behaviour was heavily oriented towards the centrifugal forces that pushed them away from the village to safely express their emotion and pain: "men's greater mobility and capacity for violence once offered them another outlet for their grief. I was told that in the past a man could mantau kamawo nraya, 'carry out his grief,' by killing someone" (Atkinson 1990: 68).

\section{Marginality is a point of view}

Related to the relationship between centre and periphery and the Wana's point of view, there is the idea of marginality itself and "how discursive constructions of spatial differences between centre and periphery depend on subjective viewpoints that then serve as instruments in politics" (Alex Körner 2019: 2). Indeed, the concept of centre and periphery is based on a point of view, an observation point usually decided by the power relationships between the actors. These relationships not only construct our ideas of ourselves but also of the others, because our identity is unavoidably shaped by our relationships with others. With the shifting of the power position also the identification with the periphery or the centre changes. "In recent decades, transnational and global history have contributed to a more inclusive understanding of intellectual and cultural exchanges, challenging the ways in which we tend to assign positions of centre and periphery on our mental maps" (Alex Körner 2019: 3). In the end, the relationship between core and periphery cannot be defined in absolute terms, but I have decided to take the emic point of view of the Wana.

The most influential historian to critically adopt the centre/periphery paradigm in the 1970s was Immanuel Wallerstein. At the centre of his worldsystem analysis was a critique of the ideological foundations of modernization theory, through emphasis on the exploitative relationship between "advanced" economies and the allegedly less developed parts of the world. He argues that the modern world system is distinguished from empires by its reliance on economic control of the world order by a dominating capitalist centre (core) in systemic economic and political relation to peripheral and semi-peripheral world areas which have so far remained outside the reach of the world-system enter it at the stage of "periphery". There is a fundamental and institutionally stabilized "division of labour" between core and periphery: while the core has a high level of technological development and manufactures complex products, the role of the periphery is to supply raw materials, agricultural products, and cheap labour for the expanding agents of the core. Once established, this unequal state tends to stabilize itself due to inherent, quasi-deterministic constraints. In the end, we could apply the dependency relationship even regarding the Wana situation. Dependency theory is the notion that resources flow from a "periphery" of poor and underdeveloped states to a "core" of wealthy states, enriching the latter at the expense of the former (Wallerstein 1974). How it happened with the kayu paramba, the money tree. Indeed, the dependency is given by the difference in financial strength between centre and peripheral places particularly the inability of peripheral countries to borrow in their own currency. In this case, as a currency I intend the mythical power, the one 
needed to perform the rituals that allow the community to survive. Usually, especially in the post-colonial and capitalist realities, spatial hierarchies are based on the direction of goods. Colonial empires took raw material from a colony to bring them to the centre, leaving the periphery without economic power. In the case of the Wana, my idea is that the colonial empires, the Dutch but also all the "westerns" in general, took the mythical power of the Wana and treated is as raw material took away from its owners and brought far away. "'Core' / periphery' refers always to an unequal relation" (Petrusewicz 2019: 18) but, for the Wana, their relationship is inverted. In this culture the core is powerless while the periphery is powerful. From a Wana point of view, the goods were not taken from the periphery but from the core of the world, the Wana land, to the periphery. While this one-directional transmission, the Wana used their agency to shape this relationship and place themselves at the centre of the their and our world. Regarding the Wana, to establish an intellectual or political order that reverse the power relationship between centre and periphery. In fact, they place themselves at the centre of the world, but it is a centre that has been emptied of its power and resources, and thus powerless.

\section{Marginality as a choice}

Finally, it is also important to note that the central position, characterised by living in the jungle and remaining poor, is also a choice for Wana people. Grumblies explains how "If the millennial promise shall fulfil one day, bringing them a new Golden Era, Wana need to remain masi yasi, pitiful, poor, dumb, in other words: marginal" (2016: 123). The Wana transformed an imposed social and economic subalternity into a position of power. They inverted the periphery-centre power relationship, self-positioning at the centre of the world. Even in their immobility, Wana manage to respond to the attacks from the world and to obtain, in the future, the power that will free them. Since space, time and power overlap in Wana culture, physical and economic immobility is crucial if Wana people are to be ready for the return of the tau baraka and the restoration of the golden era. In this section, I have tried to show, though, that the word "marginal" in Grumblies' understanding here might be replaced with "central."

[Wana] claim that Muslims live their heaven here on earth, as demonstrated by their comparative wealth and preoccupation with purity. In the Muslim section of heaven [...] people live in filth (pointedly portrayed as pig excrement) and they are so hungry that their souls take the form of wild boar that root through Wana gardens in search of food. As for Christian souls, they have only scraps of clouds to eat (an apparent reference to Bible school pictures of Jesus and angels floating about on cumulus banquettes). (Atkinson 1992: 691)

This report from Atkinson shows how Wana believe that the return of the golden era will be the reward for everything they are presently suffering, 
while Christians and Muslims already live in paradise. Following this reasoning, only the Wana people who remain miskin (poor) and at the centre of the world will be in place for the restoration of the tana Wana (Wana Land) as the renewed power core of the world. In other words: "Wana, in millennial fashion, foresee a time when their now-despised religion will be accorded proper honors. If history is to be a succession of eras, as the dominant culture asserts, then it is only right that [...] history should end where it began - the first, who are now last, shall be first again" (Atkinson 1982: 692) or

Breaking out of this current marginalized standing by becoming powerful, educated and rich due to their new empowerment will make them no longer suitable for their spiritual friends, the $t a w^{7}$ baraka. They would no longer fit the bill of the pitiful marginal people; a picture that they needed to attend. Thus, some of my interlocutors expressed fears that once they would experience empowerment they would no longer be proper candidates for the taw baraka. (Grumblies 2016: 280, emphasis in the original)

It is important to underline the fact that I found Wana people generally to be pessimistic about their own lives, considering themselves to be living through an era of terrible hardship in comparison with the situation in mythical time, although they do acknowledge that their circumstances are better than those of their grandparents' generation. They face the challenges of their lives through looking ahead to the end of time as they know it and to the return of mythical time. Death and the afterlife in heaven have much in common for this yearning for mythical time; both bring the promise of better things and the fulfilment of all wishes. Heaven is also a reward for dealing with the difficulties of the current life: "Heaven is thus taken to be compensation for life on earth. For the Wana, who suffer so much in their mundane mortal existence, the afterlife offers deserved leisure and comfort" (Atkinson 1988:55). Breaking out of this current marginalized standing by becoming powerful, educated and rich due to their new empowerment will make them no longer suitable for their spiritual friends, the taw baraka. They would no longer fit the bill of the pitiful marginal people; a picture that they needed to attend. Thus, some of my interlocutors expressed fears that once they would experience empowerment, they would no longer be proper candidates for the taw baraka (Grumblies 2016: 280). Wana reality and meaning-making is based on this contrast of opposite and frequent movements between the powerful outside and the powerless inside. In fact, the powerless position that they perceive themselves to occupy at the centre of the world is also the thing due to reward them when the end of the world comes. It is a position that is geographical but above all social and economic. The movement of Wana people in the world is not physical but also on a spiritual and social level. Those Wana people who travel,

\footnotetext{
${ }^{7}$ Grumblies spells the word tau differently from Atkinson and myself.
} 
the great majority being male, obtain knowledge that translates into the power needed to become shamans, village chiefs or wise elders.

\section{Conclusion}

In the end, the Wana demonstrate how, as products of human agency, centre and periphery are conditioned by mutual dependencies. they reveal constantly evolving asymmetries between them. "Centre and periphery [...] present subjective categories defined by their discursive context. This is not to say that they are not real, but that in history, realities are shaped by the mind. In this sense [...] spatial hierarchy [is] not as a fact, but as a preference of perspective" (Alex Körner 2019: 2).

In the case of the Wana there isn't a single ongoing system - a "worldsystem" ( Wallerstein 1974) - where powerful and powerless places interact but two different worlds, inside and outside the Wana land, that can only interact when the mythological power in in motion: the dream, the ritual and the afterlife. Wana people express their agency over the external powers that constantly pressurise them, forming a "counter hegemonic discourse" (hooks 1990: 341). For hooks, marginality is not something "one wishes to lose, to give up, or surrender as part of moving into the centre, but rather as a site one stays in, clings to even, because it nourishes one's capacity to resist" (hooks 1990: 341). Of course, marginality is derived from a theoretical hierarchy and power relationships that are extremely complex and express a multifaceted condition (Dennis 2007: 2763). In fact, if from the point of view of Indonesia more widely Wana people are marginal, from the Wana point of view they are at the centre of the world. Of course, they do not have great power in either position, but while being marginalised does not give them any particular hopes for a better future, seeing themselves at the centre gives them the hope for coming rewards. Ultimately, the idea of marginality is "a material force as well as an ideological concept and a description of social reality" (Perlman 1976: 15).

In this sense, Wana culture adds new insights to wider discussions on the relationship between centre and periphery and the power relationship between genders. Moreover, Wana coping mechanism with the absence of power can cast new light on the study of minorities all over the world. To control and manage this system, Wana people use their religion to offer to each person its place in the world, and to justify their miserable life. Even if the Wana live in a very different environment and culture than the Western one we share many commonalities as humans. Among these commonalities there is the necessity to accept our powerless status regarding some of the facts of life.

With this article and with its view from a culture, I intend to push forward the discussion on the relationship between periphery and centre, especially regarding cultural minorities. In times of political turmoil, acknowledging the power relationship between communities and inside them will open new opportunity to change and discussion. As the Wana case shows, marginality isn't something imposed by an external force but something that can be embraced and transformed into something positive. 


\section{References}

Alvard, Michael S. 2000. The potential for sustainable harvests by traditional Wana Hunters in Morowali nature reserve, Central Sulawesi, Indonesia. Human Organization Vol. 59, No. 4: 428-440.

Aragon, Lorraine V. 1996. Suppressed and Revised Performances: Raego' Songs of Central Sulawesi. Ethnomusicology (Special Issue: Music and Religion) Vol. 40, No. 3: 413-439.

Atkinson, Jane Monnig. 1983. Religions in dialogue: The construction of an Indonesian minority religion. American Ethnologist Vol. 10, No. 4: 684-696.

Atkinson, Jane Monnig. 1987. The Effectiveness of Shamans in an Indonesian Ritual, in American Anthropologist, New Series, Vol. 89, No. 2: 342-355.

Atkinson, Jane Monnig. 1988. Religion and the Wana of Sulawesi, in a Dove, Michael R. (Ed.), The real and imagined role of culture in development. Case studies from Indonesia, University of Hawaii Press, Honolulu: 41- 61.

Atkinson, Jane Monnig. 1990. How gender makes a difference in Wana society, in a Jane Atkinson and Shelly Errington (Eds.), Power and difference: gender in island Southeast Asia, Stanford University press, Stanford: $52-84$

Atkinson, Jane Monnig. 1992. The art and politics of Wana shamaniship, University of California Press, Berkeley.

Atkinson, Jane Monnig. 1992. Shamanisms Today, in Annual Review of Anthropology, Vol. 21: 307-330.

Atkinson, Jane Monnig. 2003. Who appears in the family album? Writing the history of Indonesia's revolutionary struggle, in Cultural Citizenship in Island Southeast Asia: Nation and Belonging in the Hinterlands, Renato Rosaldo (Ed.), Berkeley: University of California Press: 134-161.

Belo, Jane. 1960. Trance in Bali, New York: Columbia University Press. Bresciani, Chiara

Belo, Jane. 2020. "Ya no es como antes". A critical tudy of tradition and cultural change in a Huave community, Mexico (PhD thesis manuscript), James Cook University and Aarhus University.

Coté, Joost. 1996. Colonising Central Sulawesi. The "Ethical Policy" and imperialist expansion 1890-1910, in Itinerario, Vol. 20, No. 03: 87-107.

Cresswell, Tim. 2010. Towards a politics of mobility, in Environment and Planning: Society and Space, Vol. 28, No. 1: 17-31.

Dennis, Rutledge M. 2007. Marginality, In Blackwell Encyclopedia of Sociology, G. Ritzer (Ed.), Oxford: Blackwell Publishers Ltd: 2763-65.

Denvens, Carol. 1992. "If We Get the Girls, We Get the Race": Missionary Education of Native American Girls, in Journal of World History, Vol. 3, No. 2: 219-237

Eliade, Mircea. 1971. The myth of the eternal return: or, Cosmos and history, Princeton: Princeton University Press.

Eliade, Mircea. 1972. Shamanism: Archaic Techniques of Ecstasy, Princeton: Princeton University Press.

Geertz, Clifford. 1973. The Interpretation of Cultures, New York: Basic Books. 
Grumblies, Anna-Teresa. 2016. The Construction of Marginality among Upland Groups in Indonesia: The Case of the Wana of Central Sulawesi, PhD Doctoral Thesis, University of Cologne.

Grumblies, Anna-Teresa. 2013. Being Wana, Becoming an “Indigenous People". Experimenting with Indigeneity in Central Sulawesi, in Adat and indigeneity in Indonesia: Culture and entitlements between heteronomy and self-ascription, Brigitta Hauser-Schäublin (Ed.), Göttingen Studies in Cultural Property 7. Göttingen: Universitätsverlag Göttingen: 81-98.

Harms, Erik; Hussain, Shafqat; Newell, Sasha; Piot, Charles; Schein, Louisa; Shneiderman, Sara; Turner, Terence S; Zhang, Juan. 2014. Remote and edgy: New takes on old anthropological themes, in HAU: Journal of Ethnographic Theory, Vol. 4: 361-81.

Hauser-Schäublin, Brigitta. 2013. Introduction: The power of indigeneity. Reparation, readjustments and Repositioning, in Adat and indigeneity in Indonesia: Culture and entitlements between heteronomy and selfascription, ed. Brigitta Hauser-Schäublin, Göttingen Studies in Cultural Property 7. Göttingen: Universitätsverlag Göttingen: 5-15.

hooks, bell. 1990. Marginality as a site of resistance. In Out there: Marginalization and contemporary cultures, Russell Ferguson (Ed.), Cambridge: MIT Press: 341-43.

Kartomi, Margaret J. 1973. Music and Trance in Central Java, in Ethnomusicology, Vol. 17, No. 2: 163-208

Körner, Alex. 2019. Space and Asymmetric Difference in Historical Perspective: An Introduction. In Re-Mapping Centre and Periphery, Asymmetrical Encounters in European and Global Contexts, Tessa Hauswedell, Axel Körner and Ulrich Tiedau (Eds.), UCL Press: London: 113.

Kruyt, A. C. 1930. De To Wana op Oost-Celebese, in Tijdschrift voor indische taal-, land-, en volkenkunde Vol. 70: 110-120

Kuipers, Joel C. 2011. The Society and Its Environment, in Indonesia: a country study, Frederick W. H. and Worden R. L. (Eds.), Washington: Library of Congress: 45-78.

Lahadji, Jabar. 1999. Morowali nature reserve and the Wana people, in Indigenous Peoples and Protected Areas, in South and Southeast Asia: From Principles to Practice, Colchester M. and Erni C. (Eds.), Amsterdam: Aksant Academic Publisher: 228-249.

Lahadji, Jabar. 2008. People, park and partnership. Problems and possible solutions in the Morowali Nature Reserve, in IIAS Newsletter, No. 46: 2-23.

Li, Tania M. 1999. Marginality, power and production: Analysing upland transformations, in Transforming the Indonesian uplands: Marginality, power and production, Tania M. Li (ed.), Studies in Environmental Anthropology 4, Amsterdam: Harwood: 1-45.

Mead, Margaret \& Bateson, George. 1942. Balinese character, a photographic analysis, New York: New York Academy of Sciences,

Ortner, Sherry B. 1974. Is Female to Male as Nature Is to Culture?, in Women, Culture, and Society, M. Z. Rosaldo and L. Lamphere (eds.), Stanford: Stanford University: 61-95. 
Perlman, Janice E. 1976. The myth of marginality: Urban poverty and politics in Rio de Janeiro. Berkeley: University of California Press.

Permanent Committee on Geographical Names. 2003. Indonesia. Population and Administrative Divisions, London.

Petrusewicz, Marta. 2019. Rethinking Centre and Peripheryin Historical Analysis: Land-based Modernization as an Alternative Model from the Peripheries. In Re-Mapping Centre and Periphery, Asymmetrical Encounters in European and Global Contexts, Tessa Hauswedell, Axel Körner and Ulrich Tiedau (Eds.), UCL Press: London: 17-26.

Petrusewicz, Marta. 1996. Latifundium: Moral Economy and Material Life in a European Periphery, Ann Arbor, MI: University of Michigan Press.

Picard, Michel. 2011. Introduction: "agama”, "adat”, and Pancasila, in The politics of Religion in Indonesia: Syncretism, orthodoxy, and religious contention in Java and Bali, Michel Picard and Rémy Madinier (Eds.), Oxon: Routledge: 1-20.

Prewiranegara, Shafruddin. 1984. Pancasila as the Sole Foundation, in Indonesia, No. 38: 74-83.

Rappoport, Dana. 2004. Ritual Music and Christianization in the Toraja Highlands, Sulawesi, in Ethnomusicology, Vol. 48, No. 3: 378-404.

Sachs, Curt. 1962. Wellsprings of Music, The Hague: Nijhoff

Said, Edward W. 1978. Orientalism. New York: Pantheon Books.

Sangaji, Arianto. 2007. The masyarakat adat movement in Indonesia: A critical insider's view. In The revival of tradition in Indonesian politics: The deployment of adat from colonialism to indigenism, Jamie S. Davidson and David Henley (Eds.), Routledge Contemporary Southeast Asia Series 14. London: Routledge: 319-36.

Scarduelli, Pietro. 1992. Lo specchio del cosmo. Il simbolismo spaziale nelle culture dell'Indonesia, Turin: Il Seganalibro.

Schiller, Anne. 1996. An "Old" Religion in "New Order" Indonesia: Notes on Ethnicity and Religious Affiliation, in Sociology of Religion, Vol. 57, No. 4: 409-417.

Shields, Rob. 1991. Places on the margin: Alternative geographies of modernity. London: Routledge.

Shils, Edward. 1982. The constitution of society. The Heritage of Sociology. Chicago: University of Chicago Press.

Tsing, Anna L. 1993. In the realm of the diamond queen: Marginality in an out-of-theway place. Princeton: Princeton University Press.

Wagner, Frits A. 1961. Indonesia, Milan: il Saggiatore.

Wellenkamp, Jane C. 1988. Notions of Grief and Catharsis among the Toraja, in American Ethnologist, Vol. 15, No. 3: 486-500.

Wallerstein, Immanuel. 1974. The Modern World System, I: Capitalist Agriculture and the Origins of the European World-Economy in the Sixteenth Century. New York: Academic Press.

Sitography

BPSP Sulteng. 2013. Statistik Kependudukan Sulteng 2013 (Badan Pusat Statistik Provinsi Sulawesi Tengah). Available at: 
http:/ / sulteng.bps.go.id/endback/pdf_publikasi/Statistik-

Kependudukan-Sulawesi-Tengah-2013.pdf. [Accessed 27/02/2018].

Osman, Salim. 2012. Is Atheism Illegal in Indonesia?, available at:

http:/ /jakartaglobe.id/archive/is-atheism-illegal-in-indonesia/ [Accessed 27/02/2018].

Videography

Journet, Martine; Nougarol, Gérard. 2005. Gods and Satans, Le miroir, Paris, $87 \mathrm{~min}$.

Journet, Martine; Nougarol, Gérard. 2007. The Shadow, Institut für Visuelle Ethnographie (IVE), Göttingen, 69min.

Journet, Martine; Nougarol, Gérard. 2011. Indo Pino, IRD audiovisuel, Marseille, $85 \mathrm{~min}$. 